\title{
Mexican oregano (Lippia berlandieri Schauer) oil on turkey slaughter quality
}

\section{Aceite de orégano mexicano (Lippia berlandieri Schauer) sobre la calidad en el sacrificio de pavos}

\author{
Ramón Silva-Vázquez ${ }^{1}$, José Arturo García-Macías², Lorenzo Antonio Duran-Meléndez² ${ }^{2}$ Michael E. Hume ${ }^{3}$, \\ Gerardo Méndez-Zamora ${ }^{4 *}$ \\ ${ }^{1}$ Centro de Investigación para los Recursos Naturales, Carretera Salaices km 2, CP. 33941, Salaices, López, Chihuahua, México \\ ${ }^{2}$ Facultad de Zootecnia y Ecología, Universidad Autónoma de Chihuahua, Periférico Francisco R. Almada, km 1, CP. 33820. \\ Chihuahua, Chihuahua, México \\ ${ }^{3}$ Food and Feed Safety Research Unit, Southern Plains Agricultural Research Center, Agricultural Research Service, U.S. \\ Department of Agriculture, College Station, Texas \\ ${ }^{4}$ Centro de Investigación y Desarrollo en Industrias Alimentarias, Facultad de Agronomía, Universidad Autónoma de Nuevo \\ León, Francisco Villa s/n, Ex Hacienda El Canadá, CP. 66050, Escobedo, Nuevo León, México \\ ${ }^{*}$ Autor de correspondencia: mezage@hotmail.com
}

Scientific note received: febrary 18, 2015, accepted: april 08, 2016

\begin{abstract}
The quality of slaughtered turkeys fed a diet supplemented with Mexican oregano (Lippia berlandieri Schauer) oil was investigated. Two treatments were studied. T0: control diet and T1: control diet $+400 \mathrm{mg} \mathrm{kg}^{-1}$ of oregano oil with $60 \%$ carvacrol. Live weight at slaughter was different, with T0 weighing $11.0 \mathrm{~kg}$ and T1 11.89 $\mathrm{kg}$, while the performance of feathers and drumstick was higher in T0 (4.33 and $3.18 \%$ respectively). Viscera, blood, head, neck and hot and cold carcass yield did not differ between treatments ( $p>0.05$ ). Oregano oil at $400 \mathrm{mg} \mathrm{kg}^{-1}$ can be used in the production of turkeys to influence slaughter quality.
\end{abstract}

Key words:live weight, carvacrol, yield, carcass.

RESUMEN.La inclusión de aceite de orégano mexicano (Lippia berlandieri Schauer) en dietas de pavos fue investigada sobre la calidad en el sacrificio de los pavos. Se evaluaron los tratamientos T0: dieta testigo y T1: dieta testigo $+400 \mathrm{mg} \mathrm{kg}^{-1}$ de aceite de orégano con $60 \%$ de carvacrol. El peso vivo al sacrificio de los pavos fue diferente, T0 presentó $11.0 \mathrm{~kg}$ y T1 $11.89 \mathrm{~kg}$, mientras que el rendimiento de plumas y patas fue mayor en T0 (4.33\%) que T1 (3.18 $\%)$. En tanto que en vísceras, sangre, cabeza, cuello, rendimiento de canal caliente y fría no se detectaron diferencias entre tratamientos. El aceite de orégano en $400 \mathrm{mg} \mathrm{kg}^{-1}$ puede ser usado en la producción de pavos para influir sobre la calidad en el sacrificio.

Palabras claves:peso vivo, carvacrol, rendimiento, canal.

\section{INTRODUCTION}

The turkey (Meleagris gallopavo) was among the first animals domesticated in Mexico (Canul et al. 2011), and its meat has been used as a source of protein, fat, sodium, iron and potassium (Laudadio et al. 2009). However, the market now requires meat free of microorganisms and antibiotics from the animal production system to the final product. The use of plant extracts are currently being investigated as an alternative to antibiotics in poultry production systems, so there is interest in the use of essential oils derived from herbs and spices such as oregano (Kirkpinar et al. 2014).

Oregano oil (OO) has antioxidant and antimicrobial properties, so it offers an important benefit in the livestock sector. In general, $\mathrm{OO}$ is composed of volatile substances such as carvacrol, thymol, $\beta$ myrcene, $\alpha$-terpinene, $\gamma$-terpinene, $\mathrm{p}$-cymene and cineole (Vazquez and Dunford 2005, Bakkali et al. 2008, Do et al. 2015). These characteristics give $\mathrm{OO}$ its antioxidant, antibacterial and medicinal ca- 
pacity, and its usefulness as a treatment of gastrointestinal disorders (Rivero-Cruz et al. 2011). In particular, Mexican oregano (Lippia berlandieri Schauer) is a species characterized by a strong smell, biological activity and high yield of essential oils (Dunford and Vazquez 2005, Avila-Sosa et al. 2010). The main compounds of the genus Lippia are carvacrol, thymol, cymene, pinene and linalool; these components confer its antibacterial, antioxidant, antiviral, anti-fungal and insecticidal properties (Vazquez and Dunford 2005, Ortega-Nieblas et al. 2011).

The use of oregano oil in turkey fattening has been little researched. Studies conducted so far have highlighted that $\mathrm{OO}$ could be used in the production of turkeys and that they delay lipid oxidation in the breast (Bampidis et al. 2005, Botsoglou et al. 2010, Giannenas et al. 2014). Therefore, it would be interesting to provide more information on the influence of $\mathrm{OO}$ in turkey fattening. In this sense, although a few studies have been focused on assessing lipid oxidation in turkey breast and reducing the prevalence of pathogenic bacteria with OO of Origanum vulgare L., there is little information on the effect of Mexican oregano (Lippia berlandieri Schauer) oil on turkey meat performance. Therefore, the aim of this research was to evaluate the influence of Mexican oregano essential oil added to the diet on the slaughter quality of commercial turkeys.

\section{MATERIALS AND METHODS}

Research was conducted in the Faculty of Animal Science and Ecology at the Autonomous University of Chihuahua, Chihuahua, Mexico. Chihuahua City is located between $28^{\circ} 05^{\prime}$ and $29^{\circ} 48^{\prime} \mathrm{NL}$ and $105^{\circ} 41^{\prime}$ and $106^{\circ} 38^{\prime} \mathrm{WL}$ at an elevation of 1440 masl; it has a dry temperate climate with an annual temperature range of $10-20{ }^{\circ} \mathrm{C}$ and rainfall of 200-600 mm (INEGI 2015). Turkey fattening was carried out in the Turkey Fattening Area and the slaughter process in the Faculty Meat Unit.

Two treatments were evaluated: T0 control $\operatorname{diet}($ Table 1) and T1 the control diet $+400 \mathrm{mg}$ $\mathrm{kg}^{-1}$ of $\mathrm{OO}$ (Lippia berlandieri Schauer) with 60 $\%$ carvacrol. The $\mathrm{OO}$ was acquired from the Natural Solutions company, located in Ciudad Juarez, Chihuahua. OO composition was analyzed on a PerkinElmer ${ }^{\circledR}$ Clarus 600 and SQ8 gas chromatograph. The oil was incorporated based on the weight of the diet, mixing it with the plant oil of the diets. Both treatments consisted of 700 dayold American Orlopp medium genetic line turkeys. Flock fattening lasted 18 weeks, which was carried out in different $240 \mathrm{~m}^{2}$ pens with a concrete floor and sawdust chips, 18 feeders ( $6 \mathrm{~kg}$ diet feeder ${ }^{-1}$ ) and 16 waterers $\left(8 \mathrm{~L}\right.$ waterer $\left.{ }^{-1}\right)$. The diets used were prepared based on the pre-initiation, initiation, growth, termination 1 and termination 2 stages (Table 1; NRC 1994). Feed and water were provided ad libitum throughout the fattening period. At the end of fattening the slaughter was performed to evaluate the slaughter variables, for which a completely randomized sampling of 45 unsexed turkeys was conducted per treatment, considering each turkey as an experimental unit.

Turkey feeding was suspended $12 \mathrm{~h}$ before slaughter. The slaughter process was performed according to the method used by Al-Kassie (2009) and NOM-033-ZOO (1995). Turkeys were placed on slaughter hooks, previously desensitized with an electric shock of $120 \mathrm{~V} 50 \mathrm{~Hz}$ for $5 \mathrm{~s}$, then killed with a cut in the neck to bleed them for $3 \mathrm{~min}$. Subsequently, turkeys were scalded in water at $60 \pm 1.0$ ${ }^{\circ} \mathrm{C}$ for $90 \mathrm{~s}$, and then plucked. The carcass was obtained by separating the head, drumsticks and viscera, which were then washed and placed in a cooling tub with water at $4.0 \pm 1.0^{\circ} \mathrm{C}$ for $20 \mathrm{~min}$. After this, the carcasses were removed, drained for $15 \mathrm{~min}$ and then stored at $4 \pm 1.0{ }^{\circ} \mathrm{C}$ for $24 \mathrm{~h}$.

Live weight at slaughter (LWS), weight of blood, feathers, drumsticks, head, neck, viscera and hot carcass weight were evaluated at slaughter, and then the percentage values were determined according to LWS (Kirkpinar et al. 2011). Hot carcass yield (HCY) was calculated with LWS and hot carcass weight, while cold carcass weight was obtained at $24 \mathrm{~h}$ post mortem to determine cold carcass yield ( $\mathrm{CCY})$. 
Tabla 1. Formulation of the rations used.

\begin{tabular}{lccccc}
\hline & \multicolumn{5}{c}{ Diet $^{2}$} \\
\cline { 2 - 5 } Ingredients (\%) & $\begin{array}{c}\text { Pre-initiation } \\
\text { Week 0-2 }\end{array}$ & $\begin{array}{c}\text { Initiation } \\
\text { Week 3-5 }\end{array}$ & $\begin{array}{c}\text { Growth } \\
\text { Week 6-9 }\end{array}$ & $\begin{array}{c}\text { Finalization 1 } \\
\text { Week 10-13 }\end{array}$ & $\begin{array}{c}\text { Finalization 2 } \\
\text { Week 14-17 }\end{array}$ \\
\hline Ground sorghum & 40.9 & 43.9 & 51.6 & 60.0 & 68.2 \\
Soybean meal & 50.0 & 46.5 & 39.5 & 31.5 & 23.8 \\
Dicalcium phosphate & 2.4 & 2.2 & 1.7 & 1.5 & 1.4 \\
Calcium carbonate & 1.2 & 1.5 & 1.5 & 1.5 & 1.2 \\
Vegetable oil $_{\text {Premix of vitamins and } \text { minerals }^{3}}$ & 3.0 & 4.0 & 3.8 & 3.6 & 3.5 \\
\hline
\end{tabular}

${ }^{1}$ ingredients incorporated per $\mathrm{kg}$ of diet; ${ }^{2}$ diets were formulated according to the nutritional requirements for turkeys suggested by NRC (1994); ${ }^{3}$ purified B-glucans, DL- $\alpha$ Tocopherols, zinc proteinates, selenium, vitamin $A$-acetate, protected vitamin $C$, vitamin $D_{3}$ intermediate metabolites

The data of the measured variables were subjected to analysis of variance via the PROC GLM procedure (SAS 2002), based on the statistical model: $\mathrm{y}_{i j}=\mu+\mathrm{T}_{i}+\mathrm{e}_{i j}$; where: $\mathrm{y}_{i j}=$ response variable for the effect of the $i$-th treatment; $\mu=$ overall mean; $\mathrm{T}_{i}=$ effect of the $i$-th treatment (T0 and T1); $e_{i j}=$ the residual error normally distributed with zero mean and variance $\sigma^{2}\left[\varepsilon_{i j} \sim\right.$ $\left.\mathrm{N}\left(O, \sigma^{2}\right)\right]$. Differences between treatments were determined at a significance level of 0.05 .

\section{RESULTS AND DISCUSSION}

Chromatographic analysis of the oregano oil indicated that the composition was $60.02 \%$ carvacrol, $3.96 \%$ thymol, $23.63 \%$ cineole, $9.57 \%$ pcymene, $0.11 \%$ gamma-terpinene and $2.70 \%$ other compounds. Essential oils have been recognized for their antimicrobial activity and influence on birds' productive performance (Lee et al. 2004). But few studies have evaluated the effect of $\mathrm{OO}$ on turkey characteristics at slaughter. In this study, the LWS of turkeys was different between treatments $(p<0.05)$, T1 being $890.0 \mathrm{~g}$ heavier than T0, which differs from Papageorgiou et al. (2003) and Bampidis et al. (2005), who found no effect on turkey live weight, in addition to indicating that the constituents of $\mathrm{OO}$ can stimulate feed intake and improve nutrient assimilation. In this regard, studies in chickens made with $\mathrm{OO}$ in the feed found improved chicken weight. This result can be attributed to the thymol and carvacrol, which stimulate digestibility and increase nutrient absorption (Symeon et al. 2009, Roofchaee et al. 2011,
Alali et al. 2013, Küçükyilmaz et al. 2014, MéndezZamora et al. 2015). Therefore, the increase in turkey LWS could be due to the $\mathrm{OO}$ in T1.

The influence of essential oils depends on the concentrations used in the diet (Marcinčák et al. 2011), so some of their components may have an effect on the metabolism of the birds and weight of the organs (Simsek et al. 2007). In this study the blood, viscera, head and neck showed no statistical differences between treatments (Table 2), since possibly the effect of $400 \mathrm{mg} \mathrm{kg}^{-1}$ of oregano oil added to the diet had no effect on the evaluated variables. Similar results were reported in studies by Bampidis et al. (2005) and Küçükyilmaz et al. (2014), who found no statistical differences in turkey and chicken viscera, while studies in chickens suggested that essential oils can modify hemoglobin and cholesterol, but not bird slaughter variables (Toghyani et al. 2011, Issa and Abo 2012, Küçükyilmaz et al. 2014).

Few studies have reported the effect of $\mathrm{OO}$ on turkey slaughter variables. The weight of feathers and drumsticks was different between treatments ( $p$ $<0.05)$. This may be due to the weight of the turkeys, with T1 presenting the highest LWS values. This evidence indicates a possible effect of $\mathrm{OO}$ on some turkey slaughter variables.

Turkey carcass characteristics depend on the capacity for lean tissue deposition (Firman 2004). In the evaluated treatments no statistical differences in $\mathrm{HCY}$ and $\mathrm{CCY}$ were detected (Table 2). In this regard, Lee et al. (2004) indicate that some $\mathrm{OO}$ components in diets can be deposited in the flesh of the carcass through improved digestive efficiency, 
Tabla 2. Influence of oregano oil incorporated into the diet on turkey slaughter quality.

\begin{tabular}{|c|c|c|c|c|}
\hline \multirow[t]{2}{*}{ Variables $^{1}$} & \multicolumn{2}{|c|}{ Treatments $^{2}$} & \multirow[t]{2}{*}{$\mathrm{F}$} & \multirow[t]{2}{*}{$P$ value } \\
\hline & T0 & T1 & & \\
\hline LWS (kg) & $11.00 \pm 0.13$ & $11.89 \pm 0.13$ & 22.52 & $<0.0001$ \\
\hline Feathers $(\%)$ & $4.33 \pm 0.11$ & $3.72 \pm 0.11$ & 16.04 & 0.0001 \\
\hline Drumsticks (\%) & $3.18 \pm 0.04$ & $2.91 \pm 0.04$ & 19.45 & $<0.0001$ \\
\hline Blood (\%) & $3.69 \pm 0.11$ & $3.72 \pm 0.11$ & 0.03 & 0.8533 \\
\hline Viscera $(\%)$ & $8.02 \pm 0.17$ & $8.25 \pm 0.17$ & 0.92 & 0.3408 \\
\hline Head $(\%)$ & $1.76 \pm 0.03$ & $1.71 \pm 0.03$ & 1.54 & 0.2183 \\
\hline Neck (\%) & $5.37 \pm 0.06$ & $5.29 \pm 0.06$ & 0.84 & 0.3629 \\
\hline HCY $(\%)$ & $73.65 \pm 0.24$ & $73.85 \pm 0.24$ & 0.36 & 0.5496 \\
\hline CCY (\%) & $76.56 \pm 0.29$ & $76.48 \pm 0.29$ & 0.03 & 0.8575 \\
\hline \multicolumn{5}{|c|}{$\begin{array}{l}{ }^{1} \text { LWS }=\text { Live weight at slaughter; } \mathrm{HCY}=\text { Hot carcass yield; CCY } \\
=\text { Cold carcass yield; } 2 \text { T0 = control diet; T1 } 1 \text { control diet }+400 \\
\mathrm{mg} \mathrm{kg}-1 \text { oregano oil (Lippia berlandieri Schauer; } 60 \% \text { Carvacrol); } \\
\text { Means ( } \pm \text { Standard error) and F value in the same row are signifi- } \\
\text { cantly different if } \mathrm{p}<0.05(\mathrm{n}=45) .\end{array}$} \\
\hline
\end{tabular}

while research with chickens found no effect on carcass yield with $28.8 \mathrm{mg} \mathrm{kg}-1$ of carvacrol and $300 \mathrm{mg}$ $\mathrm{kg}^{-1}$ of $\mathrm{OO}$ (Küçükyilmaz et al. 2014, Kirkpinar et al. 2014). On the other hand, with $1600 \mathrm{mg}$ $\mathrm{kg}^{-1}$ of oregano (Lippia berlandieri Schauer) oil an effect was found on hot and cold chicken carcass (Méndez-Zamora et al. 2015). With $400 \mathrm{mg} \mathrm{kg}^{-1}$ of oregano oil there was a response in turkey live weight at slaughter, without affecting hot and cold carcass yields. Therefore, further research should be carried out with higher levels of OO (Lippia berlandieri Schauer) and emphasis should be placed on studying meat quality variables such as nutrients, lipid oxidation, antimicrobial effect and preservation of food of animal origin.

\section{LITERATURE CITED}

Alali WQ, Hofacre CL, Mathis GF, Faltys G (2013) Effect of essential oil compound on shedding and colonization of Salmonella enterica serovar Heidelberg in broilers. Poultry Science 92: 836-841.

Al-Kassie GAM (2009) Influence of two plant extracts derived from thyme and cinnamon on broiler performance. Pakistan Veterinary Journal 29: 169-173.

Avila-Sosa R, Gastélum-Franco MG, Camacho-Dávila A, Torres-Muñoz JV, Nevárez-Moorillón GV (2010) Extracts of mexican oregano (Lippia berlandieri Schauer) with Antioxidant and antimicrobial activity. Food and Bioprocess Technology 3: 434-440.

Bakkali F, Averbeck S, Averbeck D, Idaomar M (2008) Biological effects of essential oils-A review. Food and Chemical Toxicology 46: 446-475.

Bampidis VA, Christodoulou V, Florou-Paneri P, Christaki E, Chatzopoulou PS, Tsiligianni T, et al. (2005) Effect of dietary dried oregano leaves on growth performance, carcase characteristics and serum cholesterol of female early maturing turkeys. British Poultry Science 46: 595-601.

Botsoglou E, Govaris A, Moulas A, Botsoglou N (2010) Oxidative stability and microbial growth of turkey breast fillets during refrigerated storage as influenced by feed supplementation with olive leaves, oregano and/or $\alpha$-tocopheryl acetate. British Poultry Science 51: 760-768.

Canul SM, Sierra VA, Durán SL, Zamora BR, Ortiz OJ, Mena DO (2011) Caracterización del sistema de explotación del Meleagris gallopavo en el centro y sur de Yucatán, México. Actas Iberoamericanas de 
Conservación Animal 1: 288-291.

Do TKT, Hadji-Minaglou F, Antoniotti S, Fernandez X (2015) Authenticity of essential oils. Trends in Analytical Chemistry 66: 146-157.

Dunford NT, Vazquez RS (2005) Effect of water stress on plant growth and thymol and carvacrol concentrations in Mexican oregano grown under controlled conditions. Journal of Applied Horticulture 7: 20-22.

Firman J (2004) Digestible lysine requirement of male turkeys in their first six weeks. International Journal of Poultry Science 3: 373-377.

Giannenas I, Papaneophytou CP, Tsalie E, Pappas I, Triantafillou E, Tontis D, et al. (2014) Dietary supplementation of benzoic acid and essential oil compounds affects buffering capacity of the feeds, performance of turkey poults and their antioxidant status, $\mathrm{pH}$ in the digestive tract, intestinal microbiota and morphology. Asian Australasian Journal of Animal Sciences 27: 225-236.

INEGI (2015) Prontuario de información geográfica municipal de los Estados Unidos Mexicanos. Instituto Nacional de Estadística y Geografía. México en Cifras: Información Nacional por Entidad Federativa y Municipios. http://www3.inegi.org.mx/sistemas/mexicocifras/. Date consulted: february 9, 2015.

Issa KJ, Abo OJM (2012) Effect of garlic powder on performance and lipid profile of broilers. Open Journal of Animal Sciences 2: 62-68.

Kirkpinar F, Ünlü HB, Özdemir G (2011) Effects of oregano and garlic essential oils on performance, carcase, organ and blood characteristics and intestinal microflora of broilers. Livestock Science 137: 219-225.

Kirkpinar F, Ünlü HB, Serdaroğlu M, Turp GY (2014) Effects of dietary oregano and garlic essential oils on carcass characteristics, meat composition, colour, $\mathrm{pH}$ and sensory quality of broiler meat. British Poultry Science 55: 157-166.

Küçükyılmaz K, Bozkurt M, Çinar M, Çatli AU, Bintas E, Erkek R (2014) The effects of an organic rearing system and dietary supplementation of an essential oil mixture on performance and meat yield of slowgrowing broilers in two seasons. South African Journal of Animal Science 44: 360-370.

Laudadio V, Tufarelli V, Dario M, D'Emilio FP, Vicenti A (2009) Growth performance and carcass characteristics of female turkeys as affected by feeding programs. Poultry Science 88: 805-810.

Lee KW, Everts H, Beynen AC (2004) Essential oils in broiler nutrition. International Journal of Poultry Science 3: 738-752.

Marcinčák S, Popelka P, Zdolec N, Mártonová M, Šimková J, Marcinčáková D (2011) Effect of supplementation of phytogenic feed additives on performance parameters and meat quality of broiler chickens. Slovenian Veterinary Research 48: 27-34.

Méndez-Zamora G, García-Macías JA, Durán-Meléndez LA, Herman-Lara E, Santellano-Estrada E, SilvaVázquez R (2015) Aceite esencial de orégano (Lippia berlandieri Schauer) en variables de calidad de la canal de pollo. Ecosistemas y Recursos Agropecuarios 2: 41-51.

NOM-033-ZOO-1995 (1995) Norma Oficial Mexicana. Sacrificio humanitario de los animales domésticos y silvestres. http://www.economia-noms.gob.mx/noms/detalleXNormaAction.do. Date consulted: february 9, 2015.

NRC (1994) National Research Council. Nutritional Requirements of Poultry. 9th Edition. Washington D.C. 
Ortega-Nieblas MaM, Robles-Burgueño MaR, Acedo-Félix E, González-León A, Morales-Trejo A, VázquezMoreno L (2011) Chemical composition and antimicrobial activity of oregano (Lippia palmeri S. Wats) essential oil. Revista Fitotecnia Mexicana 34: 11-17.

Papageorgiou G, Botsoglou N, Govaris A, Giannenas I, Iliadis S, Botsoglou E (2003) Effect of dietary oregano oil and a-tocopheryl acetate supplementation on iron-induced lipid oxidation of turkey breast, thigh, liver and heart tissues. Journal of Animal Physiology and Animal Nutrition 87: 324-335.

Rivero-Cruz I, Duarte G, Navarrete A, Bye R, Linares E, Mata R (2011) Chemical composition and antimicrobial and spasmolytic properties of Poliomintha longiflora and Lippia graveolens essential oils. Journal of Food Science 76: 309-317.

Roofchaee A, Irani M, Ebrahimzadeh MA, Akbari MR (2011) Effect of dietary oregano (Origanum vulgare L.) essential oil on growth performance, cecal microflora and serum antioxidant activity of broiler chickens. African Journal of Biotechnology 10: 6177-6183.

SAS (2002) Institute, Inc. SAS/STAT user's guide: Statics version 9 Cary, North Carolina. U.S.A.

Simsek UG, Ciftci M, Dalkilic B, Guler T, Ertas ON (2007) The effects of dietary antibiotic and anise oil supplementation on body weight, carcass characteristics and organoleptic analysis of meat in broilers. Revue de Médecine Vétérinaire 158: 514-518.

Symeon GK, Zintilas C, Ayoutanti A, Bizelis JA, Deligeorgis SG (2009) Effect of dietary oregano essential oil supplementation for an extensive fattening period on growth performance and breast meat quality of female medium-growing broilers. Canadian Journal of Animal Science 89: 331-334.

Toghyani M, Toghyani M, Gheisari A, Ghalamkari G, Eghbalsaied S (2011) Evaluation of cinnamon and garlic as antibiotic growth promoter substitutions on performance, immune responses, serum biochemical and haematological parameters in broiler chicks. Livestock Science 138: 167-173.

Vazquez SR, Dunford NT (2005) Bioactive components of mexican Oregano oil as affected by moisture and plant growth. Journal of Essential Oil Research 17: 668-671. 